\title{
Telemedicine use among neurologists before and during COVID-19 pandemic
}

\author{
Uso da telemedicina pelos neurologistas antes e durante a pandemia de COVID-19 \\ Emanuelle Roberta da Silva AQUINO ${ }^{1,5,7}$, Renan Barros DOMINGUES ${ }^{1,6}$, Carlos Eduardo MANTESE ${ }^{1,7,8}$, \\ Francisca Goreth Malheiro Moraes FANTINI², Ricardo NITRINI ${ }^{3,5}$, Gilmar Fernandes do PRADO4,9
}

\begin{abstract}
Background: After the public health emergency due to COVID-19 was declared in Brazil, the federal government temporarily regulated and authorized the use of telemedicine services for patient consultation, monitoring, and diagnosis. For more than a decade, neurologists have recognized the benefits of telemedicine in the acute management of stroke patients. However, as the use of telemedicine was restricted until the COVID-19 pandemic, the view of Brazilian neurologists about telemedicine is unknown. Methods: All neurologists registered at the Brazilian Academy of Neurology were invited by e-mail to participate in a survey about personal perceptions on telemedicine use. Results: One hundred sixty-two neurologists from all regions of Brazil answered the online questionnaire. The survey showed that 18.5\% of participants worked with telemedicine before the pandemic, while $63.6 \%$ reported working with telemedicine during the pandemic. The main telemedicine modalities used during the pandemic were teleorientation and teleconsultation. Discussion: According to our data, the COVID-19 pandemic deeply influenced the behavior of Brazilian neurologists, who developed a more favorable view about telemedicine and actively searched for information about telemedicine. As there is a need for more training in this area in Brazil, universities and medical societies must strive to improve telemedicine education. Expanding the use of high-quality teleneurology can contribute to a better care for patients with neurological diseases in Brazil.
\end{abstract}

Keywords: Telemedicine; Neurology; COVID-19; Teleneurology; Remote consultation.

\section{RESUMO}

Antecedentes: Considerando a Emergência em Saúde Pública de Importância Nacional em decorrência da infecção pelo coronavírus, o governo federal brasileiro temporariamente regulamentou o uso da telemedicina diretamente entre médico e paciente, para consulta, monitorização e diagnóstico. Há mais de uma década os neurologistas reconhecem os benefícios da telemedicina no tratamento do AVC agudo. Entretanto, como o uso da telemedicina no país era restrito até a pandemia da COVID-19, a magnitude do envolvimento dos neurologistas brasileiros com a telemedicina não é conhecida. Métodos: Todos os membros da Academia Brasileira de Neurologia foram convidados por e-mail a responder voluntariamente um questionário sobre seu envolvimento pessoal com telemedicina antes e durante a pandemia. Resultados: 162 neurologistas, representando todas as regiões do Brasil, responderam o questionário. A pesquisa mostrou que $18,5 \%$ dos respondedores trabalhavam com telemedicina antes da pandemia da COVID-19, enquanto 63,6\% afirmaram trabalhar com telemedicina durante a pandemia. As principais modalidades de telemedicina utilizadas durante a pandemia são a teleorientação e a teleconsulta. Discussão: De acordo com esses resultados, a pandemia da COVID-19 influenciou profundamente o comportamento dos neurologistas brasileiros, que passaram a demonstrar uma ideia mais favorável sobre telemedicina, e determinou uma busca ativa de informações sobre teleneurologia. Há necessidade de maior capacitação nesta área em nosso país. Universidades e sociedades médicas devem se esforçar para melhorar a educação em telemedicina. A expansão do uso da teleneurologia com alta qualidade contribuirá para um melhor cuidado dos pacientes com doenças neurológicas no Brasil.

Palavras-chave: Telemedicina; Neurologia; COVID-19; Teleneurologia; Teleconsulta.

\footnotetext{
Academia Brasileira de Neurologia, Comissão Aberta de Telemedicina, São Paulo SP, Brazil.

${ }^{2}$ Academia Brasileira de Neurologia, Comissão de Exercício Profissional, São Paulo SP, Brazil.

${ }^{3}$ Academia Brasileira de Neurologia, Diretoria Científica, São Paulo SP, Brazil.

${ }^{4}$ Academia Brasileira de Neurologia, Diretoria Executiva, São Paulo SP, Brazil.

5Universidade de São Paulo, Departamento de Neurologia, São Paulo SP, Brazil.

${ }^{6}$ Santa Casa de Misericórdia, Departamento de Neurologia, São Paulo SP, Brazil.

${ }^{7}$ Hospital Sírio Libanês, Telemedicina, São Paulo SP, Brazil.

${ }^{8}$ Hospital Mãe de Deus, Porto Alegre RS, Brazil.

${ }^{9}$ Universidade Federal de São Paulo, Departamento de Neurologia, São Paulo SP, Brazil.

Emanuelle Roberta da Silva Aquino (D) https://orcid.org/0000-0001-6178-5831; Renan Barros Domingues (iD https://orcid.org/0000-0002-6058-7937;

Carlos Eduardo Mantese (iD https://orcid.org/0000-0002-8306-803X; Francisca Goreth Malheiro Moraes Fantini (D) https://orcid.org/0000-0002-9632-6253; Ricardo Nitrini (D) https://orcid.org/0000-0002-5721-1525; Gilmar Fernandes do Prado (iD) https://orcid.org/0000-0002-3383-8198

Correspondence: Emanuelle Roberta da Silva Aquino; Email: emanurob@gmail.com.

Conflict of interest: There is no conflict of interest to declare.

Authors' contribution: ERSA, RBD, CEM: conceptualization, data curation, formal analysis, investigation, methodology, project administration, supervision, validation, writing of original draft, draft review and editing; FGMMF, RN, GFP: conceptualization, data curation, formal analysis, investigation, methodology, project administration, supervision, draft review and editing.

Received on October 15, 2020; Received in its final form on March 27, 2021; Accepted on April 01, 2021.
} 


\section{INTRODUCTION}

According to the World Health Organization, telemedicine is the remote provision of healthcare services when the distance between the providers and patients is a critical factor. Using information and communication technology, professionals exchange valid information for the diagnosis, treatment, and prevention of diseases, research, and continuing education ${ }^{1}$. The history of telemedicine begins in the early twentieth century, but the first structured system was created only in 1967, connecting the Massachusetts General Hospital with the Boston Logan Airport. With the emergence of the internet in 1990, the possibilities of telemedicine have expanded and there has been an increase in its use in several medical areas ${ }^{2}$. Telemedicine is used to integrate two or more physicians, and physicians with patients or with other health professionals, and it includes different modalities such as teleconsultation, teleorientation, telemonitoring, screening, and remote reports ${ }^{3}$.

In Brazil, telemedicine was initially regulated by the Federal Council of Medicine (CFM) in 2002 by the resolution $1643^{4}$. However, several telemedicine procedures, such as teleconsultation, were not regulated until the advent of the COVID-19 pandemic. The required social isolation determined by local health authorities imposed the need to regulate these procedures as a way to maintain medical care, not only for SARS-CoV2-infected patients but also to patients with other medical conditions. This was carried out through the ordinance $467^{5}$ of the Ministry of Health and the Law $13.989^{6}$, of April 2020. Meanwhile, the CFM has been working along with Brazilian medical specialty societies in order to establish a broader and more definitive regulation of telemedicine in Brazil.

In Neurology, telemedicine was first used more than a decade ago in the acute management of stroke patients? More recently, other areas of Neurology have been addressed in controlled studies evaluating telemedicine safety, effectiveness, cost-benefit, and patient satisfaction ${ }^{8}$. With the regulation due to the pandemic, telemedicine use had a clear increase, particularly teleconsultations, among Brazilian physicians. However, the numbers of this expansion as well as the opinions of neurologists concerning this modality of care are still largely unknown. The aim of the present survey was to better understand the use of telemedicine by Brazilian neurologists and how the COVID-19 pandemic has changed its practice.

\section{METHODS}

E-mails were sent to all neurologists registered at the Brazilian Academy of Neurology (ABN - Academia Brasileira de Neurologia) (a total of 3,441) with an open invitation to participate in a survey on personal perceptions of telemedicine use. Students and non-neurologists were not included. An anonymous and confidential questionnaire was sent, with four demographic questions and eleven multiple choice questions related to neurological care and telemedicine prior to COVID-19 pandemic and after the telemedicine authorization. The estimated time to complete the questionnaire was seven minutes. The questionnaire was designed on the online platform Survey Monkey and it was available from April 28 to June 2, 2020, with confidentiality guarantee (the original questionnaire and its English version are available in the appendix). Because of the anonymity of the participants, the $\mathrm{ABN}$ authorized the use of the data and the publication of the results.

\section{RESULTS}

One hundred sixty-two neurologists answered the questionnaire. The mean age was 44.26 years, 87 were female (53.7\%), and the mean time of neurology practice as specialist was 15.02 years. The participants were from all regions of Brazil, the majority from the Southeast (58.6\%). The five states with the largest number of participants were São Paulo (53), Minas Gerais (23), Rio Grande do Sul (17), Rio de Janeiro (15), and Bahia (7).

The survey showed that only $18.5 \%$ of the participants worked with telemedicine before the pandemic. A small number of respondents declared previously having studied the teleneurology principles (31.7\%) and $40.2 \%$ had participated in scientific meetings about telemedicine. During the pandemic, $82.7 \%$ declared having studied teleneurology, $63.6 \%$ to be applying telemedicine, and $68.5 \%$ declared to have attended at least one telemedicine scientific meeting in this period.

Figure 1 shows the telemedicine modalities used by the survey participants. Among the 59 neurologists who said they were not applying telemedicine during the pandemic, 22 reported using at least one modality of telemedicine, the

Modalities of telemedicine used by the survey participants

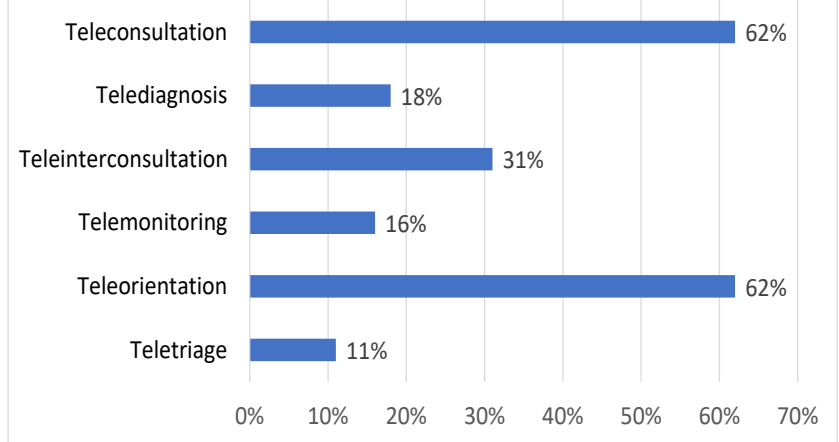

Figure 1: Modalities of telemedicine used by the survey participants. 
most used one being teleorientation (16 participants), indicating that they make unaware of their sporadic use of this technology.

Among participants who did not use telemedicine before the pandemic, $85.4 \%$ reported using communication technology to remotely connect with patients. Communication tools included mobile phone, messaging app, e-mail, and recorded videos of patients. Among those who reported using telemedicine, $86.7 \%$ used such tools, showing that the difference was not significant.

\section{DISCUSSION}

The COVID-19 pandemic led to an improvement in the use of telemedicine in our country ${ }^{9,10}$. According to our data, the pandemic deeply influenced the behavior of Brazilian neurologists who have developed a more favorable idea about this modality of care and also determined a more active search for information about telemedicine. During the first months of the pandemic in Brazil, many online meetings on telemedicine were offered. The ABN also released information on telemedicine and remote neurological examination and organized a web conference on teleneurology.

About one third of participants who answered that they did not work with telemedicine actually reported using some telemedicine modality. One possible explanation for this is that telemedicine and teleconsultation are sometimes perceived as synonymous, indicating the need to increase the medical education in this area. Including telemedicine in the medical school curriculum would probably decrease this knowledge gap in the future. Another intriguing point was that some neurologists who reported not using telemedicine prior to the pandemic, actually used technological devices to communicate with patients, unaware that this use is included in the telemedicine concept, which reinforces the need to increase the medical knowledge in this field. It is important that these complimentary uses of telemedicine, such as exchanging messages with patients and using mobile videos for epileptic attacks recognition ${ }^{11,12}$, be recognized as telemedicine procedures that are subject to regulation, so that they can be carried out with safety for patients and neurologists.

Some previous Brazilian experiences with telemedicine have been published, including the Belo Horizonte-Telehealth
(BH-Telehealth) Program ${ }^{13}$, teledermatology in primary care in São Paulo ${ }^{14}$, neurology teleinterconsultation in three capitals in Brazil ${ }^{15}$, the TelessaúdeRS-UFRGS ${ }^{16}$ program for teleregulation of care $^{17}$, neurosurgery emergency consultation ${ }^{18}$, teleophthalmology in primary care ${ }^{19}$, and medical support by teleconsultation in emergency departments ${ }^{20}$. Most of these initiatives have government support through public universities or hospitals that are members of the Institutional Development Support Program of the Unified Health System (PROADI-SUS).

Despite previous experiences, this is the first survey about the use of telemedicine among neurologists in Brazil. Since this modality of healthcare has not been previously regulated in the country, it seems that it was less used than in other countries $^{21}$, which was reinforced by the low percentage of self-declared telemedicine users in our survey. The pandemic has led to a significant increase in the number of neurologists using telemedicine even in the United States, where teleneurology is more widespread ${ }^{22}$. With the pandemic and the need for rapid regulation, a change in the use of telemedicine resources by Brazilian physicians probably occurred, and our data suggest that this was the case among neurologists.

The current study had some limitations, such as the small number of respondents. Also, it is possible that respondents were more interested in this subject that non-respondents. In 2019, a vast debate about telemedicine was launched in Brazil with a new resolution by the Federal Council of Medicine that ended up being revoked, which probably also influenced the response rate of the survey. However, as a preliminary survey, the present findings show that a trend for change is under way concerning the use of telemedicine by neurologists in different regions of Brazil.

In conclusion, this preliminary study indicates a huge increase in the use of, and in the level of interest in, telemedicine by neurologists in Brazil, influenced by the social restrictions imposed by the pandemic. The data also highlights the need to increase knowledge in this area. The more efficient application of high quality teleneurology according to international standards of safety will contribute to a better care for patients with neurological diseases in Brazil.

\section{ACKNOWLEDGEMENTS}

We thank the ABN for their support with the questionnaire.

\section{REFERENCES}

1. WHO. A health telematics policy in support of WHO's Health-For-All strategy for global health development: report of the WHO group consultation on health telematics, 11-16 December, Geneva, 1997 [Internet]. Geneva, Switzerland: World Health Organization; 1998 [cited 2020 Aug 26]. 39p. Available from: https://apps.who.int/iris/ handle/10665/63857
2. Bashshur RL, Howell JD, Krupinski EA, et al. The Empirical Foundations of Telemedicine Interventions in Primary Care. Telemed J E Health. 2016 May;22(5):342-75. https://doi.org/10.1089/ tmj.2016.0045

3. Craig J, Patterson V. Introduction to the practice of telemedicine.J Telemed Telecare 2005;11(1):3-9. 
4. Federal Council of Medicine. Resolution No. 1,643/2002, of August 7, 2002. [Internet]. Brasília; 2002 [cited 2020 Aug 26]. Available from: https://sistemas.cfm.org.br/normas/visualizar/resolucoes/ $\mathrm{BR} / 2002 / 1643$

5. Ministry of Health. Ordinance No. 467, of March 20, 2020. [Internet]. Brasília: Diário Oficial da União; 2020 [cited 2020 Aug 26]. Available from: https://www.in.gov.br/en/web/dou/-/portaria-n-467-de-20-demarco-de-2020-249312996

6. Brazil. Law No. 13,989, of April 15, 2020. [Internet]. Brasília: Diário Oficial da União; 2020 [cited 2020 Aug 26]. Available from: https:// www.in.gov.br/en/web/dou/-/lei-n-13.989-de-15-de-abrilde-2020-252726328

7. Mazighi M, Meseguer E, Labreuche J, et al. TRUST-tPA trial: Telemedicine for remote collaboration with urgentists for stroke-tPA treatment. J Telemed Telecare. 2017 Jan;23(1):174-80. https://doi. org/10.1177/1357633X15615762

8. Hatcher-Martin JM, Adams JL, Anderson ER, et al. Telemedicine in neurology: Telemedicine Work Group of the American Academy of Neurology update. Neurology. 2020 Jan 7;94(1):30-8. https://doi. org/10.1212/WNL.0000000000008708

9. Carvalho CRR, Scudeller PG, Rabello G, et al. Use of telemedicine to combat the COVID-19 pandemic in Brazil. Clinics (São Paulo). 2020;75:e2217. https://doi.org/10.6061/clinics/2020/e2217

10. Caetano R, Silva AB, Guedes ACCM, et al. Challenges and opportunities for telehealth during the COVID-19 pandemic: ideas on spaces and initiatives in the Brazilian context. Cad Saude Publica. 2020;36(5):e00088920. https://doi.org/10.1590/0102-311X00088920

11. Tatum WO, Hirsch LJ, Gelfand MA, et al. Assessment of the Predictive Value of Outpatient Smartphone Videos for Diagnosis of Epileptic Seizures. JAMA Neurol. 2020 May 1;77(5):593-600. https://doi. org/10.1001/jamaneurol.2019.4785

12. Giordano V, Koch H, Godoy-Santos A, et al. WhatsApp Messenger as an Adjunctive Tool for Telemedicine: An Overview. Interact J Med Res. 2017 Jul 21;6(2):e11. https://doi.org/10.2196/ijmr.6214

13. Rezende EJC, Tavares EC, Alves HJ, et al. Teleconsultations in public primary care units of the city of Belo Horizonte, Brazil: profile of patients and physicians. Telemed J E Health. 2013 Aug;19(8):613-8. https://doi.org/10.1089/tmj.2012.0179

14. Giavina Bianchi M, Santos AP, Cordioli E. The majority of skin lesions in pediatric primary care attention could be managed by Teledermatology. PLoS One. 2019 Dec 2;14(12):e0225479.

15. Mantese CE, Aquino ERS, Figueira MD, et al. Telemedicine support for primary care referrals to neurologist consult: decision making between different specialists when guiding the case over the phone. Arq Neuropsiquiatr. 2021 Apr;79(4):299-304. https://doi. org/10.1590/0004-282X-ANP-2020-0137

16. Harzheim E, Gonçalves MR, Umpierre RN, et al. Telehealth in Rio Grande do Sul, Brazil: Bridging the Gaps. Telemed J E Health. 2016 Nov;22(11):938-44. https://doi.org/10.1089/tmj.2015.0210

17. Katz N, Roman R, Rados DV, et al. Access and regulation of specialized care in Rio Grande do Sul: the RegulaSUS strategy of TelessaúdeRS-UFRGS. Cien Saude Colet. 2020 Mar;25(4):1389-400. https://doi.org/10.1590/1413-81232020254.28942019

18. Esteves LA, Ribeiro AT, Silva EGD, et al. Evaluation of safety, effectiveness and reproducibility of telemedicine for neurosurgical screening. Einstein (São Paulo). 2019 Aug 22;17(4):eA04609. https:// doi.org/10.31744/einstein_journal/2019A04609

19. Lutz de Araujo A, Moreira TC, Rados DRV, et al. The use of telemedicine to support Brazilian primary care physicians in managing eye conditions: The TeleOftalmo Project. PLoS One. 2020 Apr 2;15(4):e0231034. https://doi.org/10.1371/journal.pone.0231034

20. de Souza CHA, Morbeck RA, Steinman M, et al. Barriers and Benefits in Telemedicine Arising Between a High-Technology Hospital Service Provider and Remote Public Healthcare Units: A Qualitative Study in Brazil. Telemed J E Health. 2017 Jun;23(6):527-32. https://doi. org/10.1089/tmj.2016.0158

21. Dorsey ER, Topol EJ. State of Telehealth. N Engl J Med. $2016 \mathrm{Jul}$ 14;375(2):154-61. https://doi.org/10.1056/NEJMra1601705

22. Sharma A, Maxwell CR, Farmer J, et al. Initial experiences of US neurologists in practice during the COVID-19 pandemic via survey. Neurology. 2020 Aug 4;95(5):215-20. https://doi.org/10.1212/ WNL.0000000000009844 


\section{Original questionnaire (Portuguese):}

Pesquisa para os membros da Academia Brasileira de Neurologia (ABN) sobre TELEMEDICINA

1) Idade:

2) Sexo:

3) Há quantos anos é neurologista?

4) Em que estado você atua (se atuar em mais de um estado, selecione o principal)?

5) Antes do início da pandemia COVID-19, você buscava estudos e evidências científicas nas áreas de Teleneurologia e Exame Neurológico através de Telemedicina?

$\square \operatorname{Sim}$

$\square$ Não

6) Antes do início da pandemia COVID-19, você já havia participado de evento(s) científico(s) presencial(is) ou online sobre Telemedicina ou Teleneurologia?

$\square \operatorname{Sim}$

$\square$ Não

7) Antes do início da pandemia COVID-19, você trabalhava com TELEMEDICINA?

$\square \operatorname{Sim}$

$\square$ Não

8) Se sim, você já atuava com TELEMEDICINA:

$\square$ Em serviço privado, com atividades apenas para o setor privado / saúde suplementar

$\square$ Em serviço privado, com atividades também de apoio ao SUS

$\square$ Em serviço público

9) Após o início da pandemia COVID-19, você tem buscado estudos e evidências científicas nas áreas de Teleneurologia e Exame Neurológico através de Telemedicina?

$\square \operatorname{Sim}$

$\square$ Não

10) Após o início da pandemia COVID-19, você participou de evento(s) científico(s) sobre Telemedicina ou Teleneurologia?

$\square \operatorname{Sim}$

$\square$ Não

11) Após o início da pandemia COVID-19, você tem trabalhado com TELEMEDICINA?

$\square \operatorname{Sim}$

$\square$ Não

12) Se sim, você passou a trabalhar com TELEMEDICINA:

$\square$ Em serviço privado, com atividades apenas para o setor privado / saúde suplementar

$\square$ Em serviço privado, com atividades também de apoio ao SUS

$\square$ Em serviço público 
13) Que modalidade(s) de telemedicina você utiliza ou já utilizou (você pode marcar mais de uma modalidade)?

$\square$ Teleconsulta

$\square$ Telediagnóstico

$\square$ Teleinterconsulta

$\square$ Telemonitoramento

$\square$ Teleorientação

$\square$ Teletriagem

14) Se for o caso, que plataforma você tem utilizado para seus atendimentos em telemedicina?

$\square$ Plataforma específica para o teleatendimento

$\square$ Plataformas de comunicação a distância já existentes (Zoom, Whatsapp, Google Meet, etc...)

15) Antes das discussões sobre telemedicina na era COVID-19, você já havia utilizado meios eletrônicos para contato remoto direto com o paciente (Whatsapp, telefone, e-mail, Skype, etc), recebido vídeos de pacientes mostrando eventos paroxísticos e achados de exame físico ou utilizado softwares de monitoramento?

$\square \operatorname{Sim}$

$\square$ Não

16) Se você participa ou já participou de serviços de TELEMEDICINA no SUS, qual o serviço? (Responda apenas se sentir-se confortável em nos informar).

17) Esse questionário é anônimo. APENAS se desejar, se identifique (nome e e-mail), para que futuramente você também possa contribuir com sua experiência em nossas discussões sobre telemedicina:

\section{English version:}

Survey about experience with telemedicine of members of the Brazilian Academy of Neurology (ABN-Academia Brasileira de Neurologia).

1) Age:

2) Gender:

3) How many years have you been a neurologist?

4) What State do you work in?

5) Before the start of the COVID-19 pandemic, have you ever searched for publications and scientific evidence in teleneurology and neurological examination through telemedicine?

$\square$ Yes

$\square$ No

6) Before the start of the COVID-19 pandemic, have you ever participated in scientific events, in person or online, about telemedicine and teleneurology?

$\square$ Yes

$\square$ No

7) Before the start of the COVID-19 pandemic, did you work with telemedicine?

$\square$ Yes

$\square$ No 
8) If yes, did you work with telemedicine:

$\square$ In private care, with activities only for the private sector / supplementary health.

$\square$ In private care, with activities related to the SUS (Sistema Único de Saúde) also.

$\square$ In public care.

9) After the beginning of the COVID-19 pandemic, have you searched for publications and scientific evidence in teleneurology and neurological examination through telemedicine?

$\square$ Yes

$\square$ No

10) After the beginning of the COVID-19 pandemic, did you participate in scientific events about telemedicine and teleneurology?

$\square$ Yes

$\square$ No

11) After the beginning of the COVID-19 pandemic, have you been working with telemedicine?

$\square$ Yes

$\square$ No

12) If yes, you are working with telemedicine:

$\square$ In private care, with activities only for the private sector / supplementary health.

$\square$ In private care, with activities related to the SUS (Sistema Único de Saúde)

$\square$ In public service.

13) What modalities of telemedicine do you use or have used? (you can choose more than one option):

$\square$ Teleconsultation

$\square$ Telediagnosis

$\square$ Teleinterconsultation

$\square$ Telemonitoring

$\square$ Teleorientation

$\square$ Teletriage

14) If applicable, what platform have you been using for your telemedicine consultations?

$\square$ Specific telemedicine platform

$\square$ Existing remote communication platforms (Zoom, Whatsapp, Google Meet, etc...)

15) Before the discussions about telemedicine in the COVID-19 period, have you ever used electronic devices for remote contact with patients (Whatsapp, phone, email, Skype, etc.), received videos from patients showing paroxysmal events and physical examination findings, or used monitoring softwares?

$\square$ Yes

$\square$ No

16) If you participate or have participated of telemedicine services in the SUS, which was the service? (Answer only if you feel comfortable informing us).

17) This is an anonymous questionnaire. Identify yourself (name and email) only if you wish to contribute with your experience in future discussions on telemedicine. 